\title{
RELATIVE CLAUSE CONSTRUCTIONS IN NKAMI
}

\author{
Rogers Krobea Asante \& Qiuwu Ma
}

\begin{abstract}
This paper provides a systematic descriptive account of relative clause constructions (RCCs) of Nkami, an endangered Ghanaian language, based on synchronic data. It addresses issues that are of general interest in relativization, typology, syntax and grammaticalization. Among other things, it is observed that in Nkami's RCCs both the head noun and its referent within the relative clause (RC) are explicitly stated, save when the referent is inanimate in non-subject function. Thus, Nkami is among the very few languages that employ the pronoun retention strategy to obligatorily state relativized NPs in subject position within RCs. It also departs from the norm of some Kwa linguists by recognizing a marker, which is similar in distribution and function to what is so-called 'Clause (final) Determiner (CD)', as a Relative Marker (cf. Lefebvre 1993, Saah 2010). Hence, Nkami's RCC is couched as one that employs a 'bracket strategy', where two enclosing relative makers are simultaneously placed at the ends of the RC (cf. Kuteva and Comrie 2005). Moreover, unlike most Kwa languages, the head noun is never flanked by a definite determiner. Lastly, we suggest that both relativizers evolved from demonstratives.
\end{abstract}

Keywords: Nkami, relative clauses, relativization, typology, syntax, grammaticalization

\section{Introduction ${ }^{1}$}

1.1. Relative clauses. A relative clause construction (RCC) typically consists of two independent clauses, a main clause (MC) and an embedded clause, which share a common argument. The embedded clause, called the relative clause (RC), syntactically modifies and may semantically help restrict the reference of a head noun within the MC. Thus, the RC functions as a modifier to a head noun that appears within the MC. The head noun that is modified by the RC is often referred to as the 'head' of the RC (cf. Comrie and Smith 1977, Lehmann 1984, Givón 2001, Comrie 1998, Kuteva and Comrie 2005, Payne 1997, Saah 2010). On the basis of the position of the head noun, RCs are often grouped into: prenominal, postnominal, internally headed, and headless; depending on whether the RC appears before the head noun, after the head noun, within the RC, and when the head noun is not overtly expressed within the RCC. Payne (1997: 326) observes that languages generally have the distinct tendency for postnominal RCs irrespective of the order of nouns and their word-level modifiers "probably due to a universal pragmatic principle that shifts "heavy," i.e., long, phonologically complex, information to late in the clause".

Dixon (2010), however, argues against the use of the term 'head' since for him, underlyingly, all RCs modify a head noun within a noun phrase. Thus, there is nothing like a 'headless' RC if the purpose of investigation is on understanding the underlying structure rather than just the surface realization of underlying structures. As a result, Dixon calls the NP modified by the RC a 'common argument (CA)' within the RCC. And for him, the CA is "the kingpin-or binding

1 The first author thanks the Chinese Scholarship Council and the Endangered Language Development Project (ELDP) for sponsoring his PhD programme and fieldwork project respectively. For the people of Nkami, this is yours. 
element-of a relative clause construction. It functions as an argument within the underlying structure of the MC and of the RC" (Dixon 2010: 317). Thus, the common argument is made up of the so-called 'head', and the relativized NP within the RC which may be covertly or overtly stated (e.g. via gap, retention pronouns and relative pronoun). Another important aspect of the RC is the element(s) which marks the boundary of the RC. In some languages, the RC may be marked by a relative marker, as illustrated in (1a) by that; in most Indo European languages, it is marked by a relative pronoun, as shown in (1b) by who; and in some others by intonation; inter alia.

(1) a. The pen that [Max bought $\boldsymbol{0}]$ is big. ${ }^{2}$

b. The man [who married Angie] is rich.

In this paper, we will observe the following to be true about Nkami's relative clause constructions: ${ }^{3}$

- That Nkami's RCC is made of at least two independent clauses functioning as one sentence.

- That Nkami employs the 'bracket' or 'enclosing' strategy, where two relative markers ní and amú are placed at both ends of the RC to mark its boundary.

- That both relative markers ní and amó are not only multi-functional but are also homophonous with forms that function as demonstratives of various types.

- That the position of the RC is strictly postnominal in Nkami.

- That the head noun and its referent within the RC are overtly and obligatorily expressed.

- That the head noun never takes a definite determiner, e.g. amó 'the/that' and ná 'this'.

- That Nkami predominantly employs the pronoun retention strategy, where a resumptive pronoun which co-references the head noun in person, number and/or animacy is utilized to explicitly state the referent of the head noun within the RC.

- That, like Akan (Schachter 1973), certain underlying low tones in the RC are substituted for by high tones.

- That the RC always restricts the reference of the head noun and that there is no element whether segmental, suprasegmental, or written that is employed to mark the difference between 'restrictive' and 'non-restrictive' RCs.

- That the RC enjoys virtually all the morphosyntactic and grammatical properties available to main cause. Thus, the RC has a predicate which takes core and peripheral arguments, and enjoys all grammatical operatives (i.e. aspect-tense-modality, negation, direction, subject agreement, etc.) which are available to the MC.

Since Nkami is an unknown endangered undocumented language, and/or in order for a better appreciation of our discussion, the ensuing section briefly introduces the background of the language and people.

2 All RCs appear in brackets "[ ]". The head noun and its corresponding resumptive pronoun are in bold.

3 This paper forms part of an on-going $\mathrm{PhD}$ thesis which is part of a larger documentation project. The database includes spontaneous spoken and designed texts collected from about a hundred speakers of varied backgrounds in a period of one year in Amankwa, where the language is spoken. Annotation and verification of data were done in conjunction with a team of two adult Nkami speakers and several other language consultants. 
1.2 Nkami Language. Nkami refers to both a group of people and to an endangered undocumented language spoken by about four hundred people residing in Amankwa, which is a few kilometres away from the western shore of the Volta Lake in the Eastern Region of Ghana. However, more Nkamis live outside the spoken region. Presently, the majority of Nkami children do not learn Nkami as their first language; they first learn Akan and sometimes Ewe before Nkami, though almost all adult Nkamis in Amankwa speak a little Nkami. The orthography being used in this paper conforms to the orthography developed recently for the Nkami language project (led by the first author), the first attempt to introduce the language to the linguistic world. Based on intraand extra-linguistic factors, Asante (2016) argues that Nkami should be placed in the South-Guang of the Guang language group, a sub-family of the Kwa Niger-Congo phylum.

Nkami shares with regional languages most of the areal-typological linguistic features. Like other South-Guang, but unlike North-Guang languages, it has both phonemic oral and nasal vowels. Consonants are articulated at seven different places of articulation, and it has a phonemic voiceless double-articulated stop $/ \mathrm{kp} /$, unlike most Guang languages, which have the voiced counterpart $/ \mathrm{gb} /$ as well. It has two basic level tones (high and low) and manifests both lexical and grammatical functions of tone. Similar to other Guang languages, functional high tone morphemes typically trigger high tone spread to following syllable(s). It has a dominant $\mathrm{CV}$ syllable structure with other minor types: V, CVC and VC (where final C is a nasal or /w/) in descending frequency. There is evidence of three major vowel harmonic processes, ATR, labial, and height, where the last two are secondary to the first (Akanlig-Pare and Asante 2016). Typical of most Guang languages (Casali 2002), [+ATR] is the dominant feature, manifesting prototypical regressive assimilation within and across word boundaries. Like Akan, but unlike most Kwa languages including Ewe (Aboh 2010), it shows residues of a decayed noun class system; for example, number is marked on the noun stem. Affixation, reduplication and compounding are the dominant morphological processes, with verb features expressed by prefixes and verbal particles, as in most Kwa languages (Dakubu 1988).

The position of nominal modifiers, both word-level and clause-level, is post-nominal. Coding of 'predicative' property is prototypically expressed through possessive/locative constructions (and less via adjectives, verbs and nouns), while 'attributive' property is mainly expressed through relative clause constructions. It has dominant AVO and SV sentence types, and it is basically isolating with some agglutinating and a handful of fusional tendencies. Classic examples of constructions involving multi-verbs and clause combinations such as serial verb, relative clause, complement clause, adverbial clause and coordinate constructions are also found (cf. Asante 2016). Here, the reader may first refer to section 2 for an overview of the tense-aspect system of the language before proceeding further.

1.2 Overview: Nkami relative clauses. This sub-section is the springboard for the paper, presenting an overview of the canonical features of RCCs in Nkami. Consider the examples in $(2-3){ }^{4}$

4 Unless for the purpose of clarity, only high tones, represented by the acute accent ( '), are marked. 


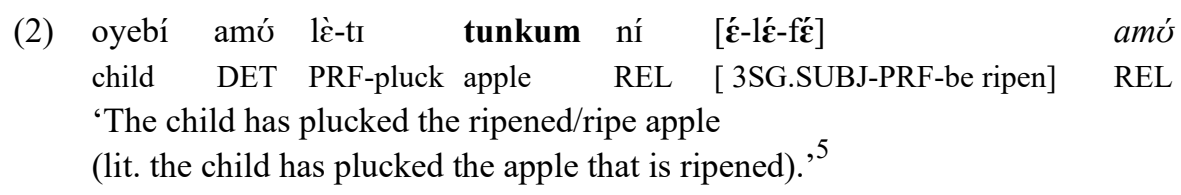

(3) a. oyebí amó lè-tI tunkum

child DET PRF-pluck apple

'The child has plucked the apple.'

b. tunkum amú lè-f $\varepsilon$

apple DET PRF-be ripen

'The apple has/is ripened.'

The sentence in (2) is a paradigmatic example of RCCs in Nkami. Underlyingly, it is made up of two independent clauses which share a common argument. So, in (2) there are two potential clauses involved: oyebí amú lètì tunkum amó 'The child has plucked the apple' and tunkum amó lèfर́ 'The apple has/is ripened', as shown in (3). Since tunkum 'apple' is the common argument shared by the two independent clauses in (3a-b), it eventually emerges as the head noun of the NP modified by the RC ćléf '́ 'it has/is ripened'. In Nkami the head noun always precedes its modifying RC just like descriptive modifiers (e.g. descriptive adjectives, numerals and determiners). So, in (2) the head noun tunkum 'apple' appears to the left of the RC ćlćf'́ 'it has ripened'. Moreover, the statement of the common argument within the $\mathrm{RC}$ which co-references the head noun in number, person and/or animacy is always stated, except when it is inanimate in non-subject role. Thus, as we observe in (2), the inanimate subject pronoun $\varepsilon^{-}$' 'it' serves as the common argument within the RC and it agrees with the head noun tunkum 'apple' in number and animacy. Thus, Nkami predominantly employs the resumptive pronoun strategy to explicitly indicate the referent of the common argument within the RC.

Nkami also employs two obligatory relative markers $n i ́$ and amú, which together co-function to define the boundaries of the RC. As we observe in (2), ní always appear immediately after the head noun and immediately before the RC. Amú, on the other hand, always appear just after the $\mathrm{RC}$ and before any other element following the RC. Moreover, observe that the RC $\varepsilon^{\prime} \varepsilon^{\prime} f_{\varepsilon}^{\prime}$ 'it has ripened' in (2) has all the features that an independent clause possesses. Fé 'ripen', as an intransitive verb, has an obligatory subject (S) pronoun $\varepsilon$ - 'it' and it is also morphologically marked by inflecting for the perfect aspectual marker lí-. Last but not least, take note that the underlying low tone syllables, $\grave{\varepsilon}^{-}$'it' (see section 3) and the perfect aspectual prefix $l \grave{\varepsilon}$ - in (3), are realized high ćléf $\varepsilon^{\prime}$ in the RC in (2). ${ }^{6}$ Having discussed the canonical features of Nkami's RCCs, we now turn to look at the various features in detail.

The rest of the paper is arranged as follows: section 2 - the structure of the RC; section 3 - the form of the relativizer; section 4 - the statement of the relativized NP within the RC; section 5 which nominal types can be modified by an RC?; section 6 - what are the permissible functions for

5 Note that there is no difference between 'the apple that has/is ripened' and 'the ripe/ripened apple' in Nkami. Many attributive properties in Nkami are expressed via RCs only.

6 We assume that the surface realization of high tones on the syllables in the RC is triggered by the preceding high tone of the relativizer $n i$. 
the head noun and its corresponding resumptive pronoun?; section 7 - restrictive and non-restrictive RCs; section 8 - lines of diachronic development; and section 9 - conclusion.

\section{The structure of the relative clause construction}

One of the critical characteristics of RCCs is that the embedded RC must be capable of standing alone as an independent clause. Dixon (2010: 348) remarks that "An RC can never be in imperative or interrogative mood. Apart from this, it may have virtually all the possibilities open to an MC...” The RC in Nkami enjoys virtually all morphosyntactic and grammatical properties available to an independent MC. As we observed in the section 1.2, all RCs have explicit predicates (either main verb or copula verb), and the predicates take all core and peripheral arguments. Moreover, the predicate within the RC inflects for all grammatical operatives (e.g. aspect-tense-modality, negation, direction, subject agreement, etc.) which are applicable to the predicate in the MC. In what follows, we examine tense-aspect marking in RCCs. But before we go into details, an overview of the tense-aspect system of the language may be in order. Nkami has

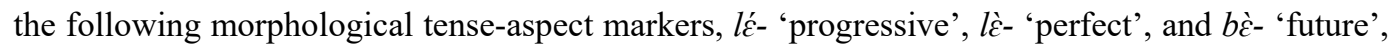
which are prefixed to the verb. They are used in the sentences in (4) where Kof $i$ is a male name, yIrI is 'stand' and mó is 'there'.

(4) a. Kofi lé-yírí mú 'Kofi is (in the process of) standing there'.

b. Kofi lè-yırı mú 'Kofi has stood there.'

c. Kofi b̀̀-yırı mú 'Kofi will stand there.'

Syllables in a grammatical/phonological word, consisting of a subject pronoun and a verb stem, generally associate with high tones when a sentence is found in the habitual, as (5) exemplifies.

(5) mí-yírí mú

'I stand there.'

Besides, there appears to be an emerging habitual marker jó- which we suspect to be a fusion of the $3^{\text {rd }}$ person singular pronominal prefix $\dot{j}$ - and a previously existing habitual marker. It is incipient because, apart from the $3^{\text {rd }}$ person, many speakers also use it when the subject of a clause is the $1^{\text {st }}$ person plural pronoun ani 'we', as (6) illustrates. ${ }^{8}$

(6) a. Kofi jó-yírí mú 'Kofi stands there.'

b. anI-ว̀ó-yírí mú 'We stand there.'

On the other hand, the continuative and the past are neither morphologically nor tonally marked. A sentence is realized in the past when it is predicated by a non-stative (action) verb in its bare form. For instance, the sentences in (7) are situated in the past because the verbs $b a$ 'come' and $d_{I}$ 'sleep' are action verbs.

7 Notice that there is a high tone spread from the progressive marker lé- to the verb stem yirì, becoming [yirí ]

8 Some speakers, especially the elderly, express dislike for the use of jó- with the $1^{\text {st }}$ person plural pronoun anI 'we'. 
(7) a. Kofi ba mi

Kofi come here

'Kofi came here.' b. $\mathrm{n}-\mathrm{dI}$

1SG.SUBJ-sleep

'I slept.'

Conversely, sentences are in the continuative if predicated by a stative verb, as (8) exemplifies.

(8)
a. Kofi tie abra amú sú
Kofi sit chair DET on

'Kofi is sitting on the chair.' b. m-bv ewéí

1SG.SUBJ-be.located home

'I am home.'

The sentences in (8) are said to be in the continuative because they contain stative verbs tie 'sit' and $b v$ 'be.located'. It is worth noting that since the difference between the continuative and the past is dependent on whether the main verb is stative or non-stative, some sentences in the language tend to be ambiguous when predicated by verbs that can be both stative and non-stative. Two such verbs, yIrI 'be.standing/stand' and $d \varepsilon \varepsilon$ 'be.lying/lie', occur in the following sentences.

(9) a. Kofi yirı mo 'Kofi is standing there (now) OR Kofi stood there.'

b. Kofi dec mo 'Kofi is lying there (now) OR Kofi lay there.'

The sentences in (9) could have two different interpretations because of the semantic flexibility of the verbs involved. The ambiguity is, however, erased when the context is obvious to interlocutors and/or when extra linguistic elements, for instance, temporal adverbs such as mialo 'now' and inie 'yesterday' are added to the sentence. With this background, let us now consider the RCCs below.

(10) a. Past

otfí ní [ó-tfié mí cdaló] amú ba mI

woman REL 3SG.SUBJ-give 1SG.OBJ money REL come here

'The woman who gave me the money came here.'

b. Habitual

ot fí ní [óó-tfié mí

woman REL 3SG.SUBJ.HAB-give 1SG.OBJ money REL come here

'The woman who gives me the money came here.'

c. Progressive

otfí ní [ó-ló-tfíé mí cdaló] amú ba mI

woman REL 3SG.SUBJ-PROG-give 1SG.OBJ money REL come here

'The woman who is giving me the money came here.' 
d. Perfect

ot fí ní [ó-ló-tfíé mí cdaló] amú ba $\mathrm{mI}^{9}$ woman REL 3SG.SUBJ-PRF-give 1SG.OBJ money REL come here

'The woman who has given me the money came here.'

e. Future

ot fí ní [ó-bé-tfíé mí

woman REL 3SG.SUBJ-FUT-give 1SG.OBJ money REL come here

'The woman who will give me the money came here.'

f. Continuative

otfí ní [ó-tíé Amankwa] amú ba mI

woman REL 3SG.SUBJ-live Amankwa REL come here

'The woman who lives in Amankwa came here.'

Thus, as the examples in (10) show, an RC in Nkami can occur in all tense-aspects, just as simplex clauses. Among others, predicates of RCs can also inflect for directional prefixes, $b \varepsilon-$ proximal directional prefix (PDF) and $y \varepsilon$ - distal directional prefix (DDP), as shown in (11).

(11) a. Kofí da

$$
\text { oyebí ní ['ó-bé- dí }
$$

mI] amú

K. beat.PST boy REL 3SG-PDP-sleep here REL

'Kofi beat the boy who comes to sleep there.'

b. Kofí da oyebí ní [ó-yć-dí mu ] amú

K. beat.PST boy REL 3SG-DDP-sleep there REL

'Kofi beat the boy who goes to sleep there.'

\section{The form of the relativizer}

As we saw in section one, Nkami has two markers ní and amó that co-function to realize the RC. Their main function is to define the boundaries of the RC. NI appears immediately after the head noun and just before the $\mathrm{RC}$, while amó appears right after the $\mathrm{RC}$ and before any other element following the RC within the RCC. This is roughly schematized in (12) and exemplified in (13).

(12) $[\mathrm{NP}+$ ní [relative clause] amó + other]

$\begin{array}{lllllll}\text { (13) ntontom } & \text { ní } & \text { [ý-nú } & \text { mó] } & \text { amó } & \text { dū } & \text { John } \\ \text { mosquito } & \text { REL } & {[1 \text { SG.SUBJ-see.PST }} & \text { 3SG.ANIM.OBJ] } & \text { REL } & \text { bite } & \text { John } \\ \text { 'The mosquito (that) I saw bit John.' } & & & & \end{array}$

Distinct from resumptive pronouns, neither ní nor amó shows any agreement with the head noun within the MC. Making a cross-linguistic observation about the position of the relative

9 Note that because of the high tone spread triggered by the relative marker ní, typically the structure of the $\mathrm{RC}$ in the progressive and perfect situations are identical, as (10c) and (10d) illustrate (i.e. both are

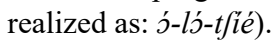


marker in RCCs, Dixon (2010: 342) observes that "A relative marker will typically occurs either at the beginning or at the end of the RC (or at both ends at once), or is added to the beginning or to the end of the verb of the RC." Examples of languages that have the relative marker occurring at the beginning, end, both ends of the relative clause, and as affix/clitic to the verb include Mupun, Mandarin Chinese, Tok Pisin, and Mojave, respectively (Dixon 2010: 342-344). Nkami may therefore be considered to be in the same group with Tok Pisin. Both employ the third strategy with the relative marker(s) occurring together at both the beginning and at the end of the RC. This strategy is referred to in the literature as the "enclosing" or "bracketing" strategy (Kuteva and Comrie 2005). However, unlike Nkami, Tok Pisin has only one relative marker which occurs at the ends of the RC, as shown in (14) (Sankoff and Brown 1976: 632 cited in Dixon 2010: 343).

$\begin{array}{lllllllll}\text { (14) meri } & \text { ia } & {\left[\mathrm{em}_{\mathrm{S}}\right.} & \mathrm{i} & \text { yangpela } & \text { meri }]_{\mathrm{RC}} & \mathrm{ai}]_{\mathrm{S}} & \mathrm{em} \mathrm{S} & \text { harim } \\ \text { woman } & \text { REL } & \text { 3SG } & \text { PRED } & \text { young } & \text { woman } & \text { REL } & 3 \mathrm{SG} & \text { listen } \\ \text { i } & \text { stap } & & & & & & & \\ \text { PRED } & \text { CONTIN } & & & & & & \end{array}$

'The woman, who was a young girl, was listening.'

Observe that, just like Nkami, Tok Pisin's relative marker $i a$ is placed before and after the RC em i yangpela meri 'who was a young girl'. Like Tok Pisin and majority of the world's languages, Nkami's relative markers $n i ́$ and amó are invariable.

Similarly to other syllables ending with the syllable $m u$ or final $/ \mho /$, amú may undergo some common phonological processes. First, the final syllable $m U$ may be omitted in speech leaving only the initial [a] on the surface. Sometimes too, only the final $/ \mho /$ of amu may be deleted followed by homorganic nasal assimilations. As a result, it may be realized on the surface as [am, an, ay, or ap] depending on the place of articulation feature of the consonant that follows it (cf. Asante 2016). Regardless of its phonetic variability, in tandem with ní, amó functions to render RCs in Nkami and so is best considered as a relative marker. That is, both are obligatory for acceptable RCCs in the language. The omission of either one or both renders infelicitous RCCs, as shown in (15b-d).

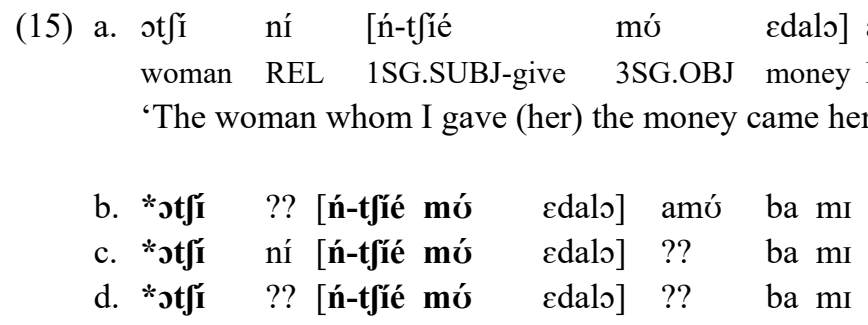

Example (15a) is acceptable because it has both ní and amó in their respective positions. The omission of $n i ́$ in (15b), amó in (15c), and both in (15d) produces ill-formed RCCs. An attempt is made in section nine to ascertain the diachronic path of $n i$ and amó. Nonetheless, it is fair to hint that, similar to cross-linguistic facts, ní and amó are not only multi-functional but are also homophonous with forms that have deictic reference. In addition to being a relative marker, ní also functions as a focus marker, a clausal connective and a proximal predicative demonstrative (PPD) in verbless clauses. These are exemplified in (16). 
(16) a. Ní as a relative marker

गjınI ní [wó-nú mó ] amú bo China man REL 2SG.SUBJ-see 3SG.OBJ REL be.in China.

'The/that man you saw is in China.'

b. $N_{I}^{\prime}$ as a focus marker

गjını ní wó-yú mú amó

man FOC 2SG.SUBJ-see 3SG.OBJ FOC

'It is a man you saw (not a woman).'

c. $N^{\prime}$ as a clausal connective

गjınI amú bu Ghana ní otfi amú bu China

'The man is in Ghana and the woman is in China.'

d. NÍ as a PPD

गुınI amú ní

man DET PPD

'This is the man.'

Details of these constructions are treated in section nine. Nonetheless, it should be mentioned here that, except for the coordinate construction in (16c), all the other three constructions constitute a single phonological unit for assigning intonation. Moreover, as we observe in (16a-b), the structures of the RCC and the focus construction could be so similar that an auditor may not be able to tell their difference until a speaker ends the utterance. Observe, for instance, that the embedded clause of the focus construction (16b), wó-yú mó 'you saw him', is realized on high tone just as the RC in (16a). Nkami's situation strengthens the observation by others (cf. Schachter 1973) that there are striking formal similarities between restrictive RC and focus constructions cross-linguistically. Nevertheless, a major difference between the two constructions is that while a focussed NP typically takes a definite determiner (unless used in a generic sense, as seen in (16b)), a head noun modified by a RC never takes a definite determiner. See in (17a and b) that when the head noun эліпI 'man' takes the determiners $n a$ ' 'this' and amớ 'that/the', the derived constructions are ill-formed.

(17) a. *opını jú ní [wú-yú mó ] amú bo China man DEM REL 2SG.SUBJ-see 3SG.OBJ REL be.in China 'This man you saw is in China.'

b. *ojınI amú ní [wơ-nú mơ] amó bo China man DET REL 2SG.SUBJ-see 3SG.OBJ REL be.in China 'The/that man you saw is in China.'

The situation is however different when the determiners $n a$ 'this' and amó appear between the focussed NP эュııI 'man' and the focus marker $n I$, as (18a-b) illustrate. 
(18) a. ojını já ní wó-nú mú amú man DET FOC 2SG.SUBJ-see 3SG.OBJ FOC 'It is this man (that) you saw.'

b. गjını amó ní wú-nú mú amú man DET FOC 2SG-see 3SG.OBJ FOC 'It is that man (that) you saw.'

This behaviour of relativized NPs in Nkami runs contrary to other Kwa languages like Akan and Ewe, which may accept a definite determiner before the relativizer. For instance, we could reproduce Saah's (2010: 95) Akan examples in (7) here as (19) by inserting the determiners $y i$ 'this' and no 'the/that', and the resulting constructions are perfectly acceptable.
a. obáá $y i$ áà [o-wáré-e
Woman DEM REL 3SG.SUBJ-marry-PST K.
Kofi] nó fi
K. CD be.from
Aburi.
'The woman who married Kofi is from Aburi.'
b. Jbáá no áà [0-wáré-e
Woman DET REL 3SG.SUBJ-marry-PST
'The woman who married Kofi is from Aburi.'
Kofi] nó fi
K. CD be.from
A.
Aburi.
A.

Like ní, amó is multi-functional. It is homophonous with the form that functions as definite article 'the' and what may be called distal demonstrative determiner 'that', as shown in (20).

$\begin{array}{llll}\text { (20) baagi } & \text { waa okpono amó asI } \\ \text { bag } & \text { wear table } & \text { DET under }\end{array}$

'There is a bag under the/that table.'

The exact function of amó in relation to skpønø 'table' in (20) is ambiguous. It could either refer to 'the table' or 'that table'. Ordinarily, amó in (20) would be given a definite article 'the' interpretation. If a speaker wants to convey a demonstrative meaning, then (20) would be supported by appropriate gestures such a pointing and eye-gaze.

In addition to being a relative marker, amú also appears to convey information that is already known to interlocutors. Functionally similar forms to amó have been called 'clause (final) determiner (CD)' in most Kwa languages. Consider the following examples from Fon (Lefebvre 1993) and Ewegbe (all cited in Saah 2010: 95).

(21) Fon: (Lefebvre 1993: 410)

\begin{tabular}{|c|c|c|c|}
\hline $\begin{array}{l}\mathbf{x w e i}_{\mathrm{i}} \\
\text { house }\end{array}$ & $\begin{array}{l}\text { [de } \\
\text { that }\end{array}$ & $\begin{array}{lll}\text { Koku } & \text { xele } & \mathbf{t i}_{\mathrm{i}} \\
\text { Koku } & \text { show } & \end{array}$ & $\begin{array}{l}\text { Asiba] } \\
\text { Asiba }\end{array}$ \\
\hline
\end{tabular}


(22) Ewegbe

Tsó atukpá si [le kplõ-a dzí] lá ná-m

take bottle REL be.located table-DEF top CD give-1SG.OBJ

'Give me the bottle which is on the table.'

Observe that, like Nkami, all three Kwa languages in (19), (21) and (22) have a particle, glossed 'clause (final) determiner (CD)', immediately following the RC. It is expressed by nó, っ, and lá in Akan, Fon, and Ewegbe respectively. Again, these forms perform similar functions that relate to "indication of old or known information" (Saah 2010: 96) or "expression of event deixis" (Lefebvre 1993: 410). Irrespective of the similarity in syntax and function of Nkami's amó to nó, o and $l a ́$, we argue that the description 'clause (final) determiners' is inappropriate for Nkami; amó is better considered as a relative marker. The reason for this is simple: If we should consider amú as clause final particle because it is phonetically and semantically related to the determiner 'the/that', then we may as well consider Nkami's (introductory) relative marker $n I ́$ as a 'clausal introductory/boundary particle', since it is the same form that links independent clauses in coordinate constructions, and marks focus in focus constructions. An obvious consequence of such a move is that it will hinder clarity of description. Consider (16a-c) as (23a-c) here, where ní is glossed as 'clause introductory particle (CIP)' and amó is glossed as 'clause (final) determiner (CD)'.

(23) a. Ní as a relative marker

गjını ní [wó-nú mó ] amó bo China

man CIP 2SG.SUBJ-see 3SG.OBJ CD be.in China

'The/that man you saw is in China.'

b. NI as a focus marker

गjını ní wó-nú mú amó

man FOC 2SG.SUBJ-see 3SG.OBJ FOC

'It is a man you saw (not a woman).'

c. Ní as a clausal connective

गnini amó bo Ghana nÍ otf I amú bo China
man DET be.in Ghana CIP woman DET be.in China
'The man is in Ghana and the woman is in China.'

Obviously, the replacement provides a more general characterisation of ní and amó in (23) than in (16). However, this will be at the expense of clarity especially to the non-native speaker reader. Clearly, the reader will be aloof as to what the data in (23) are dealing with. Are they talking about RCCs, focus clause constructions, coordinate constructions or altogether? The discussion can continue but, at the moment, we opine that, in Nkami's context, clarity is of more importance than a description that aims at 'wider' generalization. Hence, it would be more appropriate to consider ní and amó in RCCs as relative markers rather than as clausal introductory/boundary and clause (final) particles respectively. Moreover, the counterparts of amó in other Kwa languages may as well be seen as relative markers rather than CDs. They may have 'underlyingly' evolved as clause 
final markers but when they appear in relative clause constructions they perform the specific function of relative markers.

\section{The statement of the relativized NP within the RC}

As mentioned earlier, the relativized noun phrase $\left(\mathrm{NP}_{\text {rel }}\right)$ is the element within the $\mathrm{RC}$ that is co-referential with the head noun modified by a RC. Languages employ different strategies for expressing the relativized NP. Building on Comrie (1981, 1998), Kuteva and Comrie (2005: 213) tentatively identify six universal strategies for stating the relativized NP. They are: (i) relative pronoun, (ii) correlatives, (iii) internally-headed relatives, (iv) paratactic, (v) pronoun retention, and (vi) gap strategies. Based on a sample of 54 African languages, which covers all major genetic families, they found that African languages typically employ only three of the six strategies, namely gap, pronoun-retention, and correlatives. Nkami perfectly fits into their finding as it employs the pronoun retention strategy.

4.1. The resumptive pronoun. Before we begin, let us consider the pronominal system of the language. Nkami has a subject pronominal system that makes $1^{\text {st }}, 2^{\text {nd }}$ and $3^{\text {rd }}$ person distinctions. Number distinction is also made for all persons. In (24) is a list of the subject pronouns.

(24) Subject Pronouns

$\begin{array}{lllll}\text { Person } & \text { Singular } & & \text { Plural } & \\ 1 \text { st } & \text { mI-(m, }, \mathbf{y}, \mathbf{m}) & \text { 'I' } & \text { anI- } & \text { 'We' } \\ 2^{\text {nd }} & \text { WU- } & \text { 'You' } & \text { minI- } & \text { 'You' } \\ 3^{\text {rd }} \text { animate } & \mathbf{p -} & \text { 'She/he' } & \mathbf{b} \boldsymbol{\varepsilon}- & \text { 'They' } \\ 3^{\text {rd }} \text { inanimate } & \boldsymbol{\varepsilon -} & \text { 'It' } & \boldsymbol{\varepsilon}- & \text { 'They' }\end{array}$

As we observe in (24), Nkami distinguishes between animates and inanimates based on the forms of the third person subject pronouns. Thus, whenever a pronoun substitutes for a singular animate noun in subject slot of a clause, the pronominal form $\rho$ - 'she/ he/ it' is employed, while $\varepsilon$ 'it' replaces inanimate referents. This is exemplified in (25-26).
a. okplí amó be-ba. $\rightarrow$ dog DET FUT-come
'The dog will come.'
b. o-bc-ba.
3SG.ANM-FUT-come
'It will come.'
a. jáw amó be-ba.
rain DET FUT-come
$\rightarrow$
b. $\boldsymbol{\varepsilon}$-be-ba.
'The rain will come/it will rain.'
3SG.INANM-FUT-come
'It will rain/come.'

Thus, in (25b) $\supset$ - is used to replace okplí 'dog' in subject position because dog is animate, while $\varepsilon$ - replaces náw 'rain' in (26b) because rain is inanimate. Similarly, there are three persons, and singular-plural number distinctions in object/possessive pronouns, as shown in (27). ${ }^{11}$

10 A reviewer notes that Osam (unpublished) argues along this line by glossing the final element of Akan's $\mathrm{RC}$ nó as a definite relativizer (DEF REL). 
Object/Possessive Pronouns ${ }^{12}$

$\begin{array}{lllll}\text { Person } & \text { Singular } & & \text { Plural } & \\ 1^{\text {st }} & \text { mí } & \text { 'me, my' } & \text { ání } & \text { 'us, our' } \\ 2^{\text {nd }} & \text { wó (-w) } & \text { 'you, your' } & \text { míní } & \text { 'you, your' } \\ 3^{\text {rd }} \text { animate } & \text { mó (-m) } & \text { 'him/her, his/her' } & \text { ámó(ám) } & \text { 'them, their' }\end{array}$

Away from the excursus, typically the relativized position is explicitly indicated within the RC by means of a resumptive pronoun. The resumptive pronoun generally agrees with the head noun in number, person and/or animacy. For instance, in (28) the resumptive pronouns in object function $m \dot{\prime}$ 'her/him' and ámó 'them' agree with their head nouns $2 t / I$ 'woman' (28a) and at $/ I$ 'women' $(28 b)$ in person and number.

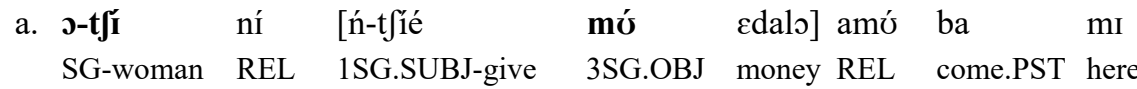 'The woman whom I gave (her) the money came here.'

b. a-t]í ní [ń-tfié ámó PL-woman REL 1SG.SUBJ-give 3PL.OBJ money REL come.PST here 'The women whom I gave (them) the money came here.'

c. o-tfí ní [jó-tfié mí SG-woman REL 3SG.SUBJ-give 1SG.OBJ money REL come.PST here 'The woman who gave me the money came here.'

\begin{tabular}{|c|c|c|c|c|}
\hline d. mI- $\varepsilon^{-}$-ś́ & dzanunum & ní & {$[\dot{\varepsilon}$-bú } & okwá] \\
\hline 1SG.SUBJ-PROG-buy & charcoal & REL & 3SG.INANM.SUBJ-have & hardness \\
\hline
\end{tabular}

Also, notice that, similar to the simplex clauses in $(25-26)$, in $(28 \mathrm{c})$ where the head noun $s t / f$ 'woman' is animate, its statement within the RC is expressed by an animate subject pronoun $j$ 'she/he'; however, in (28d) where the head noun dzanunum 'charcoal' is inanimate, it is co-referenced by an inanimate subject pronoun $\dot{\varepsilon}$ - 'it'. Thus, like simplex clauses, Nkami makes animacy distinction in the statement of the relativized NP within the RC; an animate singular head noun is co-referenced by an animate pronoun ${ }^{-}$, while its inanimate counterpart attracts an inanimate pronoun $\varepsilon$-. Saah (2010) makes an observation about resumptive pronouns of Akan in relation to Subjacency violations, which is relevant to Nkami. He writes,

11 See Asante and Akanlig-Pare (2015) for a detailed discussion of animacy in Nkami.

12 Notice that the difference between the subject and object/possessive pronouns is tonal; while the former generally associate with low tones, the latter associate with high tones. The $3^{\text {rd }}$ person inanimate object/possessive pronoun is not overtly expressed. 
Apart from using the resumptive pronouns to indicate the relativization site within the relative clause, the languages cited here are said to use this strategy to repair Subjacency violations in the Principles and Parameters (Chomsky 1981)... However ... this is not the case for Akan because there, resumptive pronouns are found even in direct object position where extraction can take place without subjacency violations. [p. 98]

Thus, like Akan, resumptive pronouns in Nkami strictly indicate the realization of the relativized NP within the RC, rather than as a strategy to repair subjacency violations. And as Saah rightly observes, the obligatory statement of the relativized NP via resumptive pronouns is not restricted to cases where the resumptive pronoun is in subject position within the RC (in which case, one could talk about subjacency violation). However, the relativized NP in Nkami, like Akan, is obligatorily expressed via resumptive pronoun in both subject and non-subject roles. Failure to have them overtly expressed results in ungrammaticalities, as exemplified in (29).

(29) a. Omission of object resumptive pronoun

$\begin{array}{lllllll}\text { *o-t fí } & \text { ní } & \text { [ń-tfié } & \text { ?? } & \varepsilon d a l \text { ] amú } & \text { ba } & \text { mI } \\ \text { SG-woman } & \text { REL } & \text { 1SG.SUBJ-give } & \text { 3SG.OBJ } & \text { money REL } & \text { come.PST } & \text { here }\end{array}$

'The woman whom I dashed (her) the money came here.'

b. Omission of subject resumptive pronoun

$\begin{array}{llllll}\text { *mI- }- \text {-s } & \text { dzanunum ní } & \text { [ ?? } & \text { - bú } & \text { okwá }] & \text { amú } \\ \text { 1SG-PROG-buy charcoal } & \text { REL } & \text { 3SG.INANM.SUBJ-have } & \text { hardness } & \text { REL } \\ \text { 'I'm buying charcoal that has hardness (I am buying hard charcoal).' }\end{array}$

The examples in (29) repeat those in (28a and 28d) above except that the resumptive pronouns have been omitted and replaced with the double question marks (“??"). As (29) shows, the omission of either the object resumptive pronoun mó 'her' in (28a) or the subject resumptive pronoun $\varepsilon^{-}$' 'it' in (28d) respectively renders the resulting sentences in (29a) and (29b) infelicitous.

In situations where the relativized NP is inanimate and plays non-subject role within the $\mathrm{RC}$, it is always null. In other words, whenever a non-subject site within the RC is meant to be occupied by an inanimate relativized NP, that site receives zero marking. In (30a-b) are RCCs that have non-human entities ntontom 'mosquito' and kāāsé 'car' as head nouns.

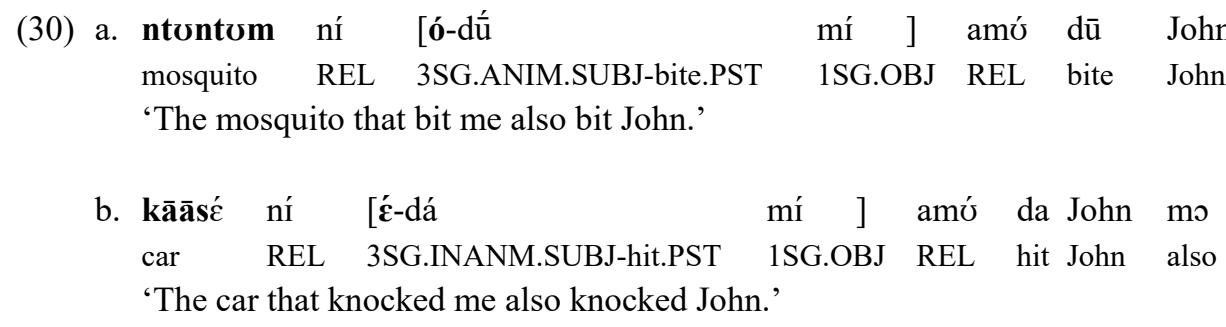

In (30a-b) the head nouns ntontom 'mosquito' and kāāsé 'car' are both overtly expressed, i.e., by $\dot{j}$ - and $\dot{\varepsilon}$ - respectively, irrespective of their animacy status, because they both occur in subject position within the RC. Observe also in (31a) that when the relativized NP ntontom 'mosquito' functions as an object within the RC, it is overtly referenced by the object resumptive pronoun mó 'it'. 
(31) a. ntontơm ní [ý-nú mó ] amú dū John mosquito REL 1SG.SUBJ-see 3SG.ANM.OBJ REL bite John 'The mosquito that I saw (it) bit John.'

b. kāāse ní [ý-nú $\quad$ o $\quad$ amú da John mo car REL 1SG.SUBJ-see 3SG.INANM.OBJ REL hit John also 'The car that I saw hit John.'

In (31b), however, because the relativized object NP within the RC co-references an inanimate head noun $k \bar{a} \bar{a} s \varepsilon$ 'car', it is not overtly expressed, thus, indicated by the zero sign $ø$. As we hinted above (27), the situation whereby entities in non-subject positions are given null representation to co-reference inanimate antecedent nominals is not peculiar to RCs. For instance, one way of showing the animacy distinction between the animate object okletI 'cat' and the inanimate object ekutu 'orange' in a simple transitive clause is through pronominalization, as shown in (32a-b).

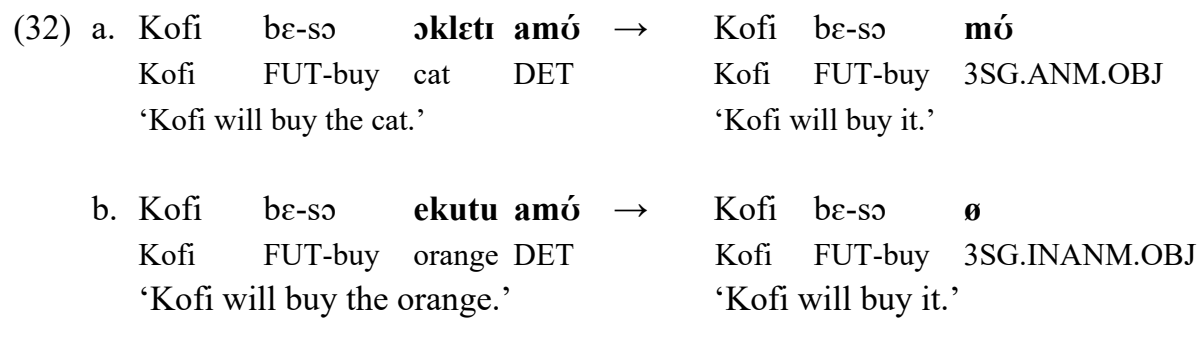

While an animate object resumptive pronoun $m u ́$ 'she/he, it' explicitly substitutes for the antecedent skletI 'cat' when pronominalized in (32a), ekutu 'orange' obligatorily receives zero marking in (32b) because it is inanimate. The use of 'zero object' or 'null resumptive' pronoun, borrowing the expressions of Stewart (1963) and Saah (2010) respectively, to refer back to inanimate antecedents in non-subject roles also occurs in extended transitive clause, content questions, focused and topicalized constructions, etc. (cf. Asante 2016). ${ }^{13}$

Nkami's extensive use of resumptive pronouns, especially in subject position, as witnessed so far, is quite phenomenal since very few languages (probably less than ten) have been identified to extensively employ the pronoun retention strategy in subject position (cf. Keenan 1985, Payne 1997, Dixon 2010, Kuteva and Comrie 2010). Keenan (1985), for instance, observes that Urhobo (Kwa, Niger-Kordofanian, Nigeria) and Yiddish are the only languages which clearly employ the pronoun retention strategy to relativize the subject position. Schaub (1985) also mentions Babungo, a Bantu language, spoken in Cameroon as another language that behaves similarly. It is also interesting to find that, apart from Nkami, two other Kwa languages of Ghana, Logba and Akan, also employ the resumptive pronoun strategy in subject position, as shown in (33-34).

13 Similar observations are made on Akan (cf. Stewart 1963, Boadi 1976, Saah 1992, 2010, and Osam 1996). 
(33) Logba: (Dorvlo 2008:174)

Jsa a xé óne imbi é ogá gú.

\begin{tabular}{|c|c|c|c|}
\hline $0-s a=a$ & xé [ó-ne & i-mbi=é ] & o-gá gú \\
\hline CM-man $=\mathrm{DET}$ & RP SM.SG.SUBJ-buy & CM-rice $=\mathrm{DET}$ & 3SG.SUBJ-pay price \\
\hline
\end{tabular}

(34) Akan: (Saah 2010: 92)

\begin{tabular}{|c|c|c|c|c|c|}
\hline [IP [NP sbáá ] [CPáà & [IP o-wáré-e & Kofi] & nó] & & Aburi]. \\
\hline woman & 3SG.SUBJ-marry-PST & $\mathrm{K}$. & $\mathrm{CD}$ & be.from & A. \\
\hline
\end{tabular}

Thus, in both Logba and Akan, the subject resumptive pronoun $\jmath$ - is obligatorily employed to co-reference the head nouns $\supset s a$ 'person' and sbáá 'woman' within the RC. In fact, just like Nkami, the omission of the subject resumptive pronoun 0 - will render the RCCs in (33-34) ill-formed. While acknowledging that the number of languages that employ the pronoun retention strategy to relativize subject position may be cross-linguistically few, based on the strong resemblance among Nkami, Akan and Logba, we incline that many Ghanaian languages, particularly those belonging to the Protou-Tano group, would behave similarly. Further research on these languages may be necessary to update linguists on the number of languages that employ this strategy. Language specific differences could also be observed among these regional languages.

\section{Which nominal type can be modified by a relative clause?}

The list of nominal types that could serve as head nouns for relativization includes: common nouns, proper nouns, pronouns, generic terms, coordinate phrases, etc. This section examines which of these can serve as head nouns for relativization in Nkami. This issue is seminal though it is rarely interrogated in discussions of RCCs. For instance, "Watters (2002: 201) states that for the Tibeto-Burman language Kham, the CA may only be $3^{\text {rd }}$ person. The same restriction applies in Jarawara (Dixon 2004a: 525). And Genetti (2007: 129) mentions that in another Tibeto-Burman language, Dolakha Newar, the CA cannot be a pronoun" (Dixon 2010: 319). Thus, in some of the world's languages, restrictions are put on the type of head nouns that could be modified in RCCs. Furthermore, recall in section 3 that while definite NPs cannot be relativized in Nkami, they can be in Akan. With my working language competence in Nkami and as a native speaker of Akan (first author), I am of the view that the most fundamental difference in relativization between the two languages is about the acceptability and non-acceptability of definite NPs as head noun.

Surprisingly, though definite NPs cannot be modified by RCs, proper names, including names of persons and places can be. This runs contrary to views expressed by some researchers, e.g., Perlmutter and Soames who state,

Proper names are used to refer to specific individuals. As a result, when the head NP of a relative clause is a proper name, it picks out the subject of the predication, leaving no role for the restrictive clause to play. Consequently, proper names cannot be heads of restrictive clauses; however, they can be heads of appositives (1979: 268-269). 
Nkami, like other Kwa language such as Akan, Ewe, and Logba do accept proper names as head nouns of NPs modified by RCs - and, in fact, when they do, the semantic effect of the RC on the proper name is identical to that of other head nouns, e.g. common nouns. In (35) are examples where a common noun, personal name, and place name serve as head nouns modified by RCs.
a. ádú ní [é-bá
$\left.f^{\prime} \varepsilon c_{f}{ }^{\prime}\right]$ amú lè-yí
war REL 3SG.INANM.SUBJ-come all
REL PRF-stand

'All the wars that arose have ended.'

b. m-fu asū amú kę Bekoe ní [ó-dzí j̀tfràmí] amú 1SG.SUBJ-take matter DET leave Bekoe REL 3SG.SUBJ-be spokesperson REL 'I delivered the message to Bekoe (who is), the chief's spokesperson.'

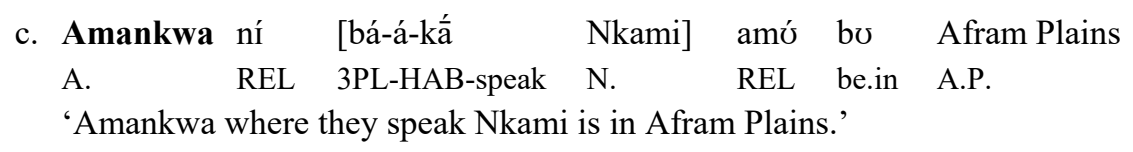

Adv 'war', a common noun; Bekoe 'personal name'; and Amankwa 'place name' serve as head nouns of the RCs in (35a, b, and c respectively). Note that the RCs in (35b and c) restrict the semantic reference of the personal names, Bekoe 'name of person' and Amankwa 'place name', just as the RC in (35a) does to the common noun adv 'war', because there could be several people and places by name Bekoe and Amankwa. The relative clauses in (35b and c) therefore have 'roles to play' as they help the auditor to know exactly who/where the speaker is talking about. ${ }^{14}$

Moreover, in Nkami only object pronouns can serve as head nouns of RC. So, if we decide to pronominalize the head noun Bekoe in (35b), we get (36).

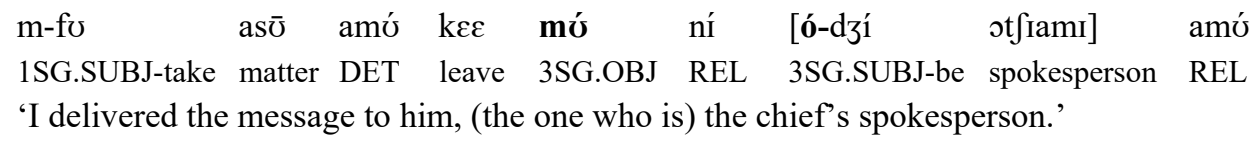

Thus, Bekoe, which functions as the object of the verb $k \varepsilon \varepsilon$ 'leave', could be replaced by an object pronoun $m \sigma^{\prime}$ 'her/him' and the resulting construction is acceptable. In English the $3^{\text {rd }}$ person singular subject pronoun (or a homophonous form) she/he can function as a head noun of a RC when used in the generic sense such as,

(37) a. He who does not work does not eat.

b. He who does not suffer does not gain.

14 A reviewer feels that the examples in (35b, and c) where the relative clauses have Bekoe 'personal name' and Amankwa 'place name' as head nouns are cases of appositive relative clauses, as Perlmutter and Soames suggest. However, as we have explained above, we do not think that they are appositive relative clauses since the RCs have restrictive roles. We think that, if anything at all, the question should be about what proper names are. It seems to us that when these proper names/nouns are used as head nouns in RCCs, they tend to have semantics that is similar to common nouns; i.e., they tend to lack the capacity to be interpreted as nouns that provide 'complete designations' (Schachter 1973) or 'unique identification' (Dixon 2010) for their referents. Consequently, the use of RCs helps speakers to lay bare the unique identities of such 'proper names/ nouns' to the fore. 
However, unlike English, Nkami's third person subject pronoun $\supset$ - never functions as the head noun of RCs. The equivalent of (37a) is provided in (38).

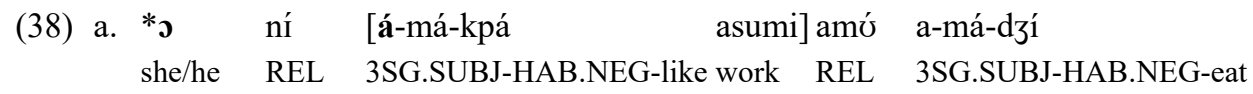

'She/he who does not like work does not eat.'

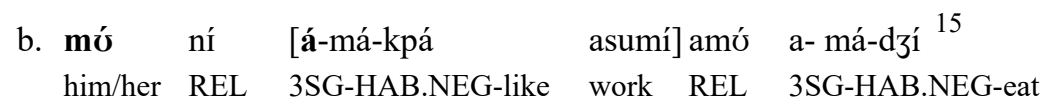

'Him (he) who does not like work does not eat.'

Example (38a) is unacceptable because it has the subject pronoun $2-$ 'she/he' as the head noun, but (38b) is felicitous because the object pronoun $m u^{\prime}$ ' $h i m /$ her' serves as the head noun. Moreover, it is the same $m \dot{v}$ that functions as head noun in what is performed by, in the words of a reviewer, 'an emphatic form of the subject pronoun in Akan', as indicated in (39). ${ }^{16}$

(39) a. Akan

ono aa [o -re-kasa ] yi, o-n-nim China.

3SG REL 3SG.SUBJ.PROG-speak DEM 3SG.SUBJ-NEG-know China

'S/he who/that is speaking (she) does not know China.'

b. Nkami

mó $\quad$ ní $\quad$ [ó-ló-klólí $\quad$ amú a-má-ní
3SG.OBJ REL 3SG.SUBJ.PROG-speak REL 3SG.SUBJ-NEG-know China
'S/he who/that is speaking (she) does not know China.'

Furthermore, it is the same form mó, which functions as head noun in RCCs, that convey similar meanings to the so-called "condensed relatives" (cf. Sweet 1891, Dixon 2010: 359) or "headless relatives" (cf. Comrie and Smith 1977, Givón 2001) in some languages. In condensed relatives or headless relatives, the head noun is fused together with the relative marker so that there is no distinct head noun separate from the relative marker. Consider some examples below.

15 The $3^{\text {rd }}$ person singular pronoun $\supset$ - undergoes lowering harmony, triggered by the low vowel in the following negative morpheme $m a$, that is why it is realized as [a].

16 It seems to us that based on Nkami's data (39b), what has been called 'emphatic subject pronoun' ono in Akan may not be an emphatic form of the subject pronoun ${ }_{-}$- 'she/he' after all, but rather, an emphatic form of the object pronoun no 'him'. Put differently, we are suggesting that the head noun ono in Akan's data (39a) may be better described as an object pronoun, but not as a subject pronoun. It appears that the description of ono as an (emphatic) subject pronoun, rather than an (emphatic) object pronoun, has been influenced by the English fine glossing/translation of such sentences. For instance, it seems to us that the literal translation of both the Akan and Nkami's sentences in (39) will read: ' $\mathrm{Him} / \mathrm{Her}$ who is speaking, he/she does not know China.', rather than, 'He/she who is speaking, he/she does not know China.' (See Asante in preparation). 
(40) a. What [I don't like] is what you always do.

b. Where [I haven't gone] you say I have gone.

c. When [I go] is when you always go.

Thus, in (40) the content question words what, where, and when serve as both the head nouns and relative markers of their RCs. While some (e.g. Comrie and Smith 1977, Givón 2001) opine that this type of RCs is headless in English, others (e.g. Dixon 2010) argue that there is no RC which is headless. For Dixon, the headless account solely relies on the surface structure rather than the underlying structure of RCCs, which for him fails to provide adequate explanatory account for such RCCs. Consequently, for him, the head noun of the NP modified by the RC, which he calls the common argument within the MC, may be covertly or overtly stated - and in this case (40), there is condensation of the head noun and the relativizer (see Dixon 2010: 317-318, 359-360 for details). Now consider the equivalents of (40a and b) in Nkami here.

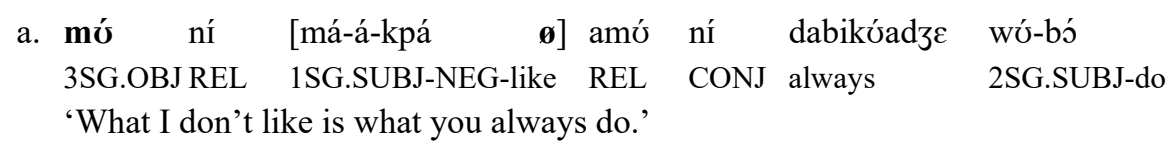

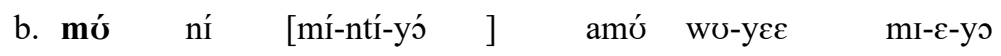 3SG.OBJ REL 1SG.SUBJ-NEG-go REL 2SG.SUBJ-say 1SG-PRF-go
'Where I haven't gone you say I have gone.'

Two observations are critical here: First, Nkami does not have condensed/headless RCCs. In all RCCs, there is an overt head noun and an overt relativizer. So, in (41), for instance, where English employs condensed relatives, in Nkami there must be overt head noun mó and relativizer ní. Secondly, in RCCs that would be expressed by condensed/headless relatives in English, Nkami employs mó as the head noun regardless of whether the condensed element is where, what or when. Thus, rather than using condensed relatives, Nkami has a peculiar case where the third person singular animate object pronoun $m u^{\prime}$ 'him/her' has extended its functions as head noun that is employed for generic referencing.

\section{What are the permissible functions for the head noun and its corresponding resumptive pronoun?}

Following Keenan and Comrie's (I977) famous piece on Accessibility Hierarchy (AH), almost every publication on RCCs discusses possible function(s) allowed for relativized NPs within RCs. The $\mathrm{AH}$ is schematized as follows:

$$
\text { Subject }>\text { object }>\text { indirect object }>\text { oblique }>\text { possessor }
$$

Simply, the AH is an implicational scale that claims that if a language allows relativization of a function on the scale, then all other function(s) preceding it (to the left) would be allowed. In other words, any language which allows, for instance, the indirect object function within an RC will also allow the object and subject functions. A language will therefore not allow an indirect object function while disallowing the object and subject functions. Majority of languages studied 
conform to the AH (cf. Payne 1997, Dixon 2010). There are, however, some exceptions to the theory, especially those languages with ergativity orientation. Because of the strong relationship between the subject of an intransitive clause (S) and object of transitive clause (O) in ergativity languages, there are cases where the $(\mathrm{S})$ and $(\mathrm{O})$ may be relativized, while $(\mathrm{A})$ is not allowed. Dyirbal and Warekena are two such languages (Dixon 2010). In order to accommodate such languages, some (cf. Dixon 2010) have called for a revision of the statement of the first two positions; i.e. subject and object, on the scale. All functions on the scale are, however, relativizeable in Nkami, as (43) illustrates.

(43) a. Subject within an RC

\begin{tabular}{|c|c|c|c|}
\hline Ma-á-kpá & skplí ní & [ó-dû́ & John] \\
\hline 1SG SUBJ-HAB NEG-like & REL & 3SG.SUBJ-bite.PST & J. \\
\hline
\end{tabular}

'I don't like the dog that bit John.'

b. Direct Object within an RC

\begin{tabular}{|c|c|c|c|}
\hline Ma-á-kpá & okplí ní & [John yú & mó ] \\
\hline 1SG.SUBJ-HAB.NEG-like & REL & see.PST & 3SG.OBJ \\
\hline
\end{tabular}

c. Object 2 of an SVC within an RC

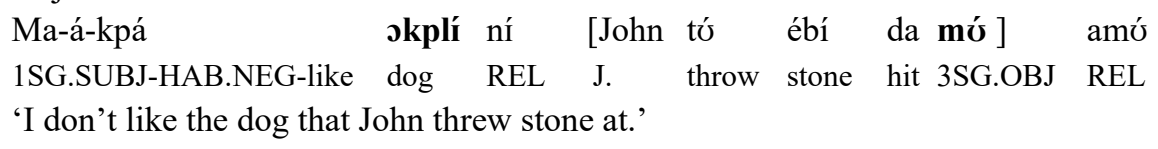

d. Oblique within an RC

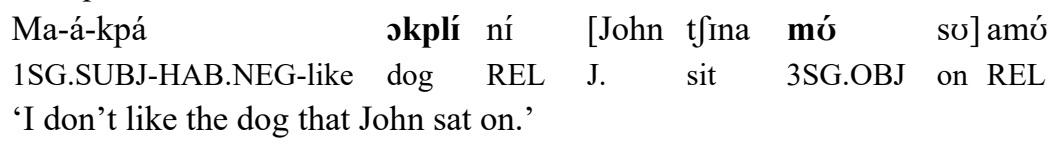

e. Possessor within an $\mathrm{RC}$

\begin{tabular}{|c|c|c|c|}
\hline Ma-á-kpá & okplí ní & [mó & bu.bo \\
\hline 1SG.SUBJ-HAB.NEG-like & REL & 3SG.POSS leg & RED.have length \\
\hline
\end{tabular}

As we observe in (43a-e), okplí 'dog' can function as subject in (43a), object in (43b), object 2 of SVC in (43c), oblique in (43d), and possessor in (43e) within each of the RCs without worry. In all sentences in (43), the head noun $s k p l i$ ' $d o g$ ' is explicitly co-referenced by a harmonious resumptive pronoun within the $\mathrm{RC}$.

Apart from the canonical functions on the AH, Nkami also allows several more complex functions within the RC. Consider the comparative and coordinate constructions in (44).

(44) a. Comparee of comparison within an RC

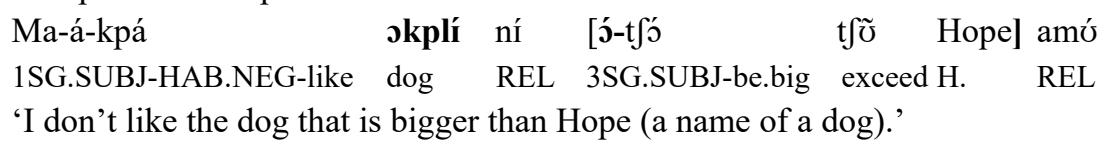


b. Standard of comparison within an RC

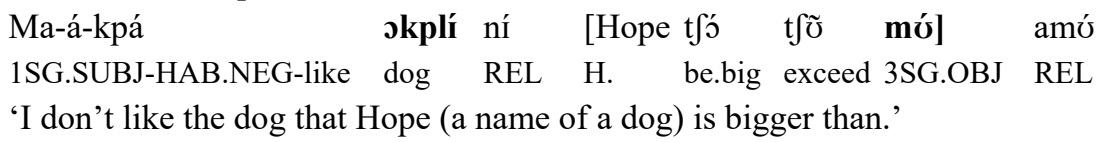

c. Coordinand of a coordinate NP within an RC

\begin{tabular}{|c|c|c|c|c|}
\hline Ma-á-kpá & oyebí ní & [Kofí ní & mó & yə Amankwa] \\
\hline 1SG.SUBJ-HAB.NEG-like & child REL & $\mathrm{CONJ}$ & 3SG.OBJ & go A. \\
\hline
\end{tabular}

Observe that in (44a-b) Nkami allows entities in comparison to be relativized within the RC. Precisely, the relativized subject pronoun $\delta$ - 'she/he' in (44a) functions as the Comparee of Comparison (subject of comparison), while mó 'it' in (44b) functions as the Standard of Comparison (object of comparison). In (44c) too, the relativized element $m o ̛$ ' 'him/her' functions as a coordinand (conjunct) of the coordinate clause Kofí ní mó 'Kofi and him'.

As mentioned earlier, following the inception of the Accessibility Hierarchy (AH), research on RCCs invariably seek to ascertain the allowable functions of the relativized NP within the RC. However, few have touched on the allowable functions for the relativized NP (head noun) within the MC. The widespread nature of this phenomenon is presumably rationalized by the fact that generally the functions allowable for the head noun within the $\mathrm{MC}$ are more than those allowed within the RC. Nonetheless, it is important to note that there are some languages such as Warekena and Yidiny (Dixon 2010: 324) that allow very limited functions for the head noun within the MC too. For instance, in Yidiny a head noun can be modified by a RC only if it functions as subject or object within the MC. Consequently, this paper examines the allowable functions for the head noun within the $\mathrm{MC}$ in Nkami. Similar to most languages, all functions allowable for the relativized NP within the RC, as we saw in (43), are also allowable for the head noun within the $\mathrm{MC}$, as illustrated in (45).

(45) a. Subject within an MC

Kofí ní [ósó-kpá at [Í ] amú ní wo-wó mú so K. REL 3SG.SUBJ.HAB-like women REL CONJ 2SG.SUBJ-follow 3SG.OBJ on 'Kofi who likes women and you are following (interested in him)?'

b. Direct object within an MC

$\begin{array}{llll}\text { Kofi jó-kpá kããsé ní } \quad \text { [é-dzí } & \text { tuntu] amú } \\ \text { K. 3SG.HAB-like car REL } & \text { 3SG.INAM.SUBJ-be } & \text { black } & \text { REL } \\ \text { 'Kofi likes cars that are black (Kofi likes black cars).' } & \end{array}$

c. Object 2 of an SVC within an MC

$\begin{array}{lllllll}\text { Kofí to } & \text { ébí } & \text { sa } & \text { okplí } & \text { ní } & {[\text { ó-d3í }} & \text { tuntu }] \text { amú } \\ \text { K. throw } & \text { stone } & \text { give } & \operatorname{dog} & \text { REL } & \text { 3SG.SUBJ-be black } & \text { REL }\end{array}$

'Kofi threw stone at the dog that is black (Kofi threw stone at the black dog).' 
d. Oblique within an $\mathrm{MC}$

Kofí t fina okplí ní [ó-dzí tuntu] amú so

K. sit dog REL 3SG.SUBJ-be black REL on

'Kofi sat on the dog that is black (Kofi sat on the black dog).'

e. Possessor within an MC

Kofí le-so okplí sa mó oka ní [ó-dzí kikibi] amú

K. PRF-buy dog give 3SG.POSS wife REL 3SG.SUBJ-be small REL

'Kofi has bought a dog for her wife who is small (for her younger wife).'

Similar to the common argument within the RC, NPs within an MC in comparative and coordinate constructions can become head nouns of RCs, as illustrated in (46).

(46) a. Standard of Comparison within an MC

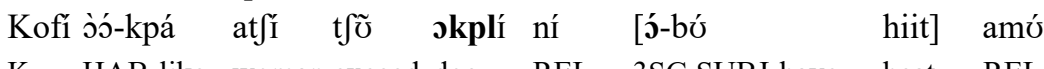

K. HAB-like woman exceed dog REL 3SG.SUBJ-have heat REL

'Kofi likes women than a dog that has heat (that is on heat).'

b. Comparee of Comparison within an MC

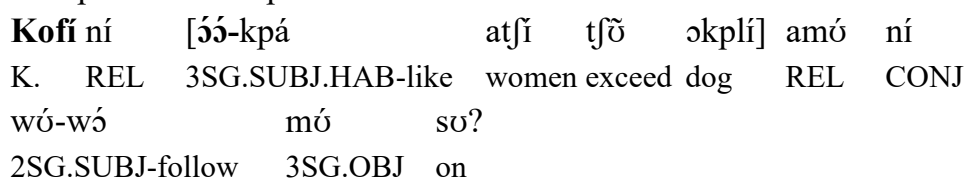

'Kofi who likes women than dog and you are following?'

c. Coordinand of Coordinate NP within an MC

y-yu Kofí ní otjí ní [ó-tíe mayu mi fã] amú

1SG.SUBJ-see K. CONJ woman REL 3SG.SUBJ-live outskirts here REL

'I saw Kofi and the lady who lives at the outskirts.'

d. Coordinate NP within an MC

$\begin{array}{lllllll}\text { y-yu Kofí ní otjí ní } & {[\text { bé-tíé mayu }} & \text { mi fã }] \text { amo } \\ \text { 1SG-see K. CONJ woman REL } & \text { 3PL-live outskirts } & \text { here } & \text { REL } \\ \text { 'I saw Kofi and the woman who live at the outskirts.' }\end{array}$

Example (46d) is interesting because it has the entire coordinate phrase Kofi ní otfí 'Kofi and woman' serving as the head noun of the RC bétié mayu mifã 'who (they) live at the outskirts'. Observe the harmony in the selection of resumptive pronouns within the RC. While stfi (46c) selects $o$ - 'she/he' because it is singular noun, Kofi ní otfII (46d) select bé- 'they' because it is coordinate phrase. ${ }^{17}$

Moreover, in Nkami a relativized element can be an NP (resumptive pronoun) within another $\mathrm{RC}$, as illustrated in (47).

17 A reiteration here may be necessary. Note that while the examples in (43-44) show evidence of the allowable functions for relativized NPs (resumptive pronouns) within RCs, those in (45-46) show allowable functions for relativized NPs (head nouns) within MCs. The relativized NPs are in bold. 
(47) Kofí ní [óó-yó

sukuu] ní [á-má-bú

عdaló] amú

K. REL 3SG.SUBJ.HAB-go school REL 3SG.SUBJ-HAB.NEG-have money REL

nI wó-kpá?

CONJ 2SG.SUBJ-like

'Kofi who goes to school, who does not have money, and you love?'

In (47) '́s- 'he.HAB' serves two functions: First, as a resumptive subject pronoun that co-references Kofi, the head noun, within the first RC; and second, as the head noun of the following relative clause ámábú cdal'́ 'who (he) does not have money'.

Last but not least, Besnier (2000) reports that in the Polynesian language, Tuvaluan, the relativized NP can be in intransitive subject (S) but not in copula subject (CS) function within the RC (Dixon 2010). As (48a) and (48b) show, Nkami has no such restriction.
a. adu ní [é-bá
féćf'́c] amú le-yí
war REL 3SG.INANM.SUBJ-come al
'All the wars that arose have ended.'
b. Ma-á-kpá okplí ní [ó-dzí timi] amú 1SG.SUBJ-NEG.HAB-like dog REL 3SG.SUBJ-be short REL
'I don't like the dog that is short (I don't like that short dog).'

In (48a) the resumptive pronoun ' $\boldsymbol{\varepsilon}$ - 'it' is in (S) function within the RC $\varepsilon$ bá féćfé 'it all came', whereas in (48b) $o$ - 'it' is in (CS) function within the RC ódzi timi 'that (it) is short'.

\section{Restrictive versus non-restrictive relative clauses}

This section investigates whether Nkami has a formal means for distinguishing 'restrictive' from 'non-restrictive' RCs. A restrictive RC is a clause that helps to delimit the semantic reference of the head noun it modifies. Thus, in (49) the relative clause 'sfiI 'she/he (who) got lost' helps to delineate the identity of oyebi amó 'the boy'.

(49) oyebí ní [ó-fíi $\quad]$ amú ní
child REL 3SG.SUBJ-get.lost REL PPD
'The child who got lost is this.'

On the other hand, in English when the identity of the head noun already has unique reference, for instance, when the element being modified by the RC is a proper name, pronoun or definite NP, the RC may be said to be 'non-restrictive'. Put differently, a non-restrictive RC merely helps to provide additional background information to the head noun rather than restricting its reference since it is already uniquely identified (Dixon 2010, Perlmutter and Soames 1979). There are several strategies that languages use to distinguish between restrictive and non-restrictive RCs. For instance, one of the strategies that English utilizes to distinguish between non-restrictive and restrictive relatives is the use of pauses, which are reflected in writing by commas before and after the RC, as (50) illustrates. 
Thus, if the boy lives in a small community where there is only one boy missing and everyone is aware and worried about his disappearance, then, the identity of the boy could easily surface if one simply said: "The boy has been found". In such a case, the RC "who got missing' may be said be adding 'parenthetical' information. Such RCs are termed 'non-restrictive'. For some other languages, definite NPs such as those that take definite determiners, names of persons, place names, and pronouns cannot be modified by (restrictive ) RCs because they are assumed to be uniquely identified and so do not need further additional information.

In Nkami, however, as we observed in section 5, with the exception of NPs that take definite determiners and subject pronouns, all definite NPs including names of persons, place names, and object pronouns can be head nouns of NPs modified by RCs. Secondly, unlike English, there is no formal mechanism, whether segmental, suprasegmental, or written for distinguishing RCs that modify uniquely identifiable head nouns from non-uniquely identifiable ones. In fact, Nkami speakers do not make any formal difference even when the head noun is the $2^{\text {nd }}$ person singular object pronoun wó 'you', the addressee in the speech act, as (51) illustrates.

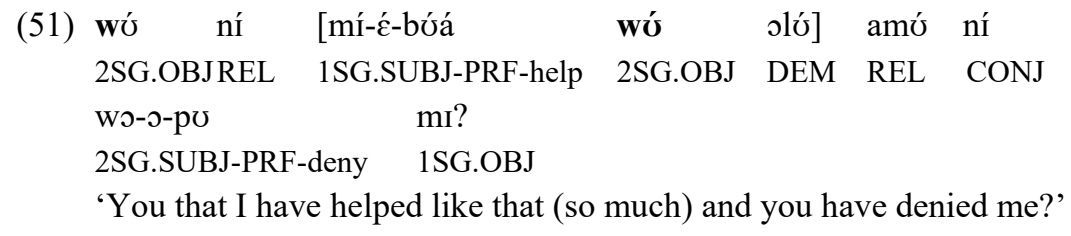

Any pause in the production of RCCs in Nkami may be as a result of the speaker's style, probably as a way of indicating emphasis, rather than marking a difference between restrictive and non-restrictive RCs. This is because, as we suggested in section 5, whenever definite NPs such as names of persons, place names, and pronouns are used as head nouns in RCCs in Nkami, they tend to lack the capacity to be interpreted as nouns that provide 'complete designations' (Schachter 1973) or 'unique identification' (Dixon 2010) for their referents. The use of RCs, therefore, helps speakers to bring out the unique identities of such 'definite NPs', rather than just providing 'parenthetical' information or 'appositive' interpretations to them. Nkami therefore seems to belong to the group of languages that do not draw a distinction between restrictive and non-restrictive RCs. This helps give credence to an observation made by Saah (2010:102) that "It seems that Akan and, most probably all the Kwa languages, only use the type of relative clause being discussed here as restrictive relatives"; and an earlier one by Watters (2000: 225) that the difference between restrictive and non-restrictive RCs "is generally not marked in African languages".

\section{Lines of diachronic development}

Dixon (2010) recommends two things to look for when establishing the development of RCCs. He remarks, "First, how did the relative clause construction in a particular language develop? And secondly, if there is an explicit marker for an RC, where did this come from?" Dixon (2010: 361). These two questions are therefore our concern in this section. 
Starting with the first, we take support from Kibrik's (1992) dual universal cognitive strategies underlying RCCs to suggest that tentatively RCCs in Nkami evolved as a result of a need to express 'attributive' properties. Our data for this analysis are based primarily on property encoding constructions in Nkami. According to Kibrik (1992), there are only two distinct global cognitive strategies that underlie the evolution of RCCs. These are the 'combining' and the 'inserting' strategies. The combining strategy involves the amalgamation of two propositions that share a common argument in the speaker's mind. Thus, the sharing of a common argument is necessary for the combination of the propositions that form RCCs. On the other hand, the inserting strategy "corresponds to a process where a referent is first conceived through its participation in a certain event, and coded by a nominalized proposition, and then this complex nomination as a single whole, is inserted into another, broader event" (Kibrik 1992:143-144).

Synchronically, there are three strategies for expressing 'predicative' in Nkami. Thus, if one wants to express something like 'John is tall/fat/strong', one of these strategies may be used: (i) through a property coding verb, (ii) through a descriptive adjective and, (iii) through a possessive clause. Let us consider them each in (52).
(52) a. oyebí amú tfó
Child DET be.big
'The child is fat.'
c. oyebí amú bo $\mathbf{\varepsilon s i ̂ ́}^{18}$
child DET have tallness
'The child has tallness (the boy is tall).'
b. oyebí amú dzi tıntın
child DET be tall
'The child is tall.'

In (52a) the property concept 'fat/big' is assigned to the entity oyebi 'child' via an intransitive verb $t \int$ ' ; in (52b) 'tall' is expressed via an adjective tıntın; and in (52c) 'tall' is expressed via a possessive complement $\varepsilon s \bar{I}$. In (53a-b) below are further examples where the property concepts 'cold' and 'light' are expressed via possessive complements oyiré 'coldness' and ssá 'lightness' respectively.
(53) a. ntfu amú bu oyíré water DET have coldness
'The water is cold.'
b. owili amú bu osá paper DET have lightness 'The paper is light (weight).'

Obviously, tf'ว 'be.big', as a verb, cannot be used attributively to modify a noun in (54a). However, tIntin 'tall', as an adjective, can modify nominals attributively, as shown in (54b).
(54) a. *oyebí țj amú child be.big DET
'The big/fat child'
b. oyebí tintın amú child tall DET 'The tall child'

18 There is a general process in Nkami where word initial front mid vowels $/ \varepsilon$, e/ delete and then compensated for by preceding round high vowels. So, oyebí amv bv esî́ is realized as [oyebí amó buv sí] 
Apart from descriptive adjectives like tintin 'tall', there are some identity nouns such as oyu 'thief', skpe 'witch', osikani 'rich person', and owurobie 'lazy person' that can also be used attributively to express identity to their attributes, as shown in (55).

(55) a. oyebí óyú amú...

child thief DET

'The child who is a thief... (lit. the thief child).'

b. oyebí ókpé amú...

child witch DET

'The child who is a witch... (lit. the witch child).'

Unlike these identity nouns, nouns such as $\varepsilon s \bar{I}$ 'tallness', oyiré 'coldness', osá 'lightness', and skwá 'hardness' that are used in possessive clauses to convey predicative property are 'defective' and hence cannot be used attributively, as (56) exemplifies.
a. *oyebí esî́ amú
child tallness DET
'The tall child'
b. *oyebi okwá amó child hardness DET
'The strong child'
c. *ntfu oyíré amó
water coldness DET
'The cold water'
d. *owilı osá amo paper lightness DET 'The light paper'

With these facts, we make a thesis: Since Nkami lacked resources to express attributive property to complement the defective nouns that are used in possessive clauses to express predicative property, speakers devised a means of expressing attributive property by combining clauses that share a common argument, as (57) shows.
(57) a. oyebí amú bu esí child DET has tallness
'The child is tall.'
b. oyebí amú ba mi child DET come here 'The child came here.'

As we observe in (57), both clauses share the subject argument oyebi ' child'. In combining the two clauses, the clause that is assumed to assign property to the common argument is made to be embedded in the other. Thus, (57a) will be embedded in (57b) because it is the one that assigns property to the common argument oyebi 'child'. Furthermore, in order to delineate the boundaries of the RC, the particles ní and amó are placed at both ends of the RC. Finally, per anaphoric substitution rule (cf. Stockwell 1977, Baker 1978), which prohibits identical elements in a sentence, a resumptive pronoun is employed to replace the head noun (i.e. oyebi 'child') within the $\mathrm{RC}$. Thus, if speakers wanted to say something like 'the tall boy came here', they would combine oyebi amú ba $m I$ 'the child came here' and oyebi amú bu esí 'the child has tallness' via inserting the latter into the former - accompanied by other language internal well-formedness constraints to arrive at oyebí ní óbú csí amú ba mi 'the child who has tallness (tall child) came here'. The process is roughly schematized in (58). 
(58) Nkami's RC derivation process
oyebí amú ba mi + oyebi amú bu esî́ $\rightarrow$ [oyebi ní obu esī amứ ba mI]
oyebí [oyebí amó bo عsî́] amú ba mI
(1) Combination via insertion
oyebí ní [oyebí amú bu esî́] amú ba mI
(2) Relative marker $n$ Í insertion
oyebí ní [ó-bú esî́ ] amứ ba mI
(3) Anaphoric substitution rule: j- replaces oyebi amú 'the child' within the RC
oyebí ní [ó-bú esî́ ] amứ ba mi Output

The contention is that RCCs evolved in Nkami because of: (i) the lack of resources (adjectives) to express certain property concepts attributively, and (ii) the need to maximize the already existing resources that were used to encode predicative property. In other words, a prototypical RCC in Nkami is one that has a property encoding possessive clause as its RC. The view expressed here is similar to the cognitive approach to grammaticalization which sees grammaticalization as a process of solving conceptualization problem by expressing more abstract concepts in terms of less abstract ones (cf. Heine et al. 1991, Bybee 2003). In (59) are other RCCs containing property encoding possessive clauses as their RCs.
a. amango ní [ع́-bú odé ] amú nú mango REL 3SG.INANM.SUBJ-have sweetness REL DPD 'That is the sweet-tasting mango (pointing to a mango tree).'

$\begin{array}{lllll}\text { b. adu ní } & \text { ['́-bú } & \text { odzá ] amú } & \text { cku ní } \\ \text { medicine REL } & \text { 3SG.INANM.SUBJ-have } & \text { hotness REL } & \text { some } & \text { PPD }\end{array}$

'This is a sample of the potent medicine (the medicine that has hotness some this).'

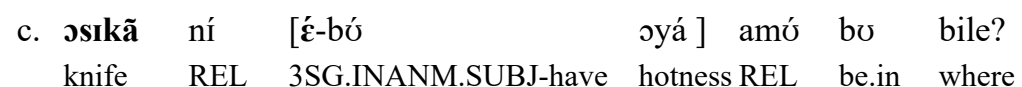

'Where is the sharp-cutting knife (where is the knife that has sharpness?)?'

Next, we determine possible diachronic paths of the two relative markers ní and amó. Recall from section 3 that both ní and amó are multi-functional. As a recap, ní is homophonous with the form used as a focus marker, clausal connective, and proximal predicative demonstrative (PPD). In (60) are examples demonstrating these distinct functions of ní. 19

(60) a. Ní as a relative marker

\begin{tabular}{|c|c|c|c|c|c|}
\hline ojini & $n i ́$ & [wú-yú & amú & bu & China \\
\hline $\operatorname{man}$ & REL & 2SG.SUBJ-see $3 \mathrm{SG} . \mathrm{OBJ}$ & REL & be.in & China \\
\hline
\end{tabular}

19 See Schachter (1973) for a discussion on some striking similarities between focus and RC constructions. 
b. $\mathrm{NI}$ as focus marker

$\begin{array}{lllll}\text { गyıni ní wó-nú mú } & \text { amú } \\ \text { man } & \text { FOC } & \text { 2SG-see } & \text { 3SG.OBJ } & \text { FOC } \\ \text { 'It is a man I saw (not a woman).' }\end{array}$

c. Ni as a clausal connective

गjını amú bo Ghana ní otfí amó bo China

man DET be.in Ghana CONJ woman DET be.in China

'The man is in Ghana and the woman is in China.'

d. Ni as a PPD

गৈInI amú ní

man DET PPD

'This is the man.'

e. गJini amú nó

man DET DPD

'This is the man.'

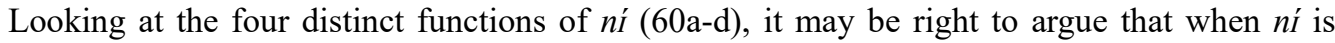
used in (60d) as a proximal predicative demonstrative, it has less abstract reference than when it performs the other three functions in $(60 \mathrm{a}-\mathrm{c})$. As a proximal predicative demonstrative (PPD), ní is used in contrast with nó in verbless clauses (60e) to express the deictic reference of entities. The other three functions are similar. $N_{I}^{\prime}$ 'underlyingly' seems to be functioning as a 'boundary/introductory linker' in all three constructions, as we observed in section 3 . The use of $n i$ as a linker is more grammatical and more abstract than as a demonstrative. As a boundary linker, $n i ́$ is not deictic. Thus, it cannot be used to indicate the location of entities in the real world as it does in (60d). Secondly, while ní contrasts $n u ̛$ when used as a demonstrative, as a linker, it is not contrastive. Thus, one cannot replace ní with nơ in (60a-c) to express deictic contrast. Lastly, as a relative marker, ní is syntactically restricted since it cannot collocate with a definite determiner (sections 3 and 5), though ní (60d) as a demonstrative can.

Moreover, apart from the cross-linguistic tendency that less abstract and less grammatical linguistic forms generally develop into forms that express more abstract and more grammatical meanings rather than vice versa, it is also widely attested that forms with deictic reference are a viable source for the development of many grammatical items including relative markers (cf. Diesel 1999, Kuteva and Comrie 2005, Dixon 2010). For instance, remarking on common sources for relative markers, Dixon 2010 remarks, "Another common source for relative markers and relative pronouns is demonstratives of various kinds". He then goes on to list Hungarian, Mupun, Tok Pisin, Yagua, etc. as examples of such languages. Kuteva and Comrie (2005: 215) also assert that the fact "That demonstratives develop into relative clause markers is certainly nothing unusual". In addition, Keenan (1985: 150) notes that "relative pronouns are commonly related to demonstratives, interrogatives, or both". Similarly to English, Keenan further observes German relative pronouns "are identical to the definite article, which itself still functions independently as a demonstrative pronoun". 
Geographically closer to Nkami is another Kwa Ghanaian language, Ewegbe. Saah (2010: 97) mentions that in Ewegbe "the element that introduces the relative clause $s i$ is derived from the proximal demonstrative sia 'this". This is exemplified below where sia 'this' is used as a demonstrative in (61a), and si as a relative marker in (61b) (Saah 2010: 97).

\section{(61) a. Tsó atukpá sia ná-m \\ take bottle this give-1SG}

'Give me this bottle.'

b. Tsó atukpá [si le kplõ-a dzí] lá ná-m

take bottle EL be-located table-DEF top CD give-1SG

'Give me the bottle which is on the table.'

As we observe in the Ewegbe data, unlike Nkami, the extension of function from a proximal demonstrative sia 'this' to a relative marker si brought about phonological depletion in the derived form (i.e. the final vowel of sia 'this' got deleted as it grammaticalized to si REL). Based on these real facts (language internal and cross-linguistic), it appears convincing that the proximal predicative demonstrative is a probable source of the relative marker and the other grammatical markers.

With regard to amó, it is homophonous with the form used as definite article 'the' and distal demonstrative 'that' (see section 3). Similarly to the argument put forward for $n i$, we posit that $a m o ́$, as a (terminal) relative marker, developed from the distal demonstrative amó. Though amó still maintains part of its 'definite' meaning 'that/the' when used as a relative marker, it is not contrastive when used in this new role. In different words, though amó can be replaced with its deictic opposite $n a$ ' 'this' to express contrast when used as a demonstrative, the same cannot be done when it (amó) functions as a relative marker in RCCs.

While it may be revealing to find that both relative markers in Nkami relate to forms that have deictic reference, it is fair to note that this phenomenon is not peculiar to Nkami. For instance, Kuteva and Comrie (2005: 222-223) cite Mbum, Ngbaka (a Central African language), and Bari (a Nilotic language) as some languages that also employ the 'bracket strategy'. And for all these languages, the markers used for delineating the boundaries of the $\mathrm{RC}$ are similar or identical to deictic elements. Of particular interest is Mbum which behaves almost identical to Nkami, as (62) illustrates.

(62) Mbum (Hagège 1970, cited in Chumbow 1977: 288)

$\begin{array}{llll}\text { úì [àí mì zày ] záy } & \text { nú bèlbél } \\ \text { woman REL I met (DET/REL) } & \text { is beautiful } \\ \text { 'The woman I met is beautiful.' } & \end{array}$

Commenting on the data above, Kuteva and Comrie (2005: 222) remark: "The forms ài and nú which delineate the relative clause are deictics of different types". Though implicit, the glossing of $z a ́ y$ as (DET/REL) appears to provide support for our decision to consider amó as a relative marker rather than a clause final determiner (section 3). It appears that the author of (62) contemplated considering záy as a REL but was also concerned about the general tendency of 
glossing such forms in the literature; therefore, he decided on a more neutral stance and went for the disjunctive glossing (DET/REL).

\section{Conclusion}

An attempt has been made in this paper to provide a systematic account of RCCs of Nkami based on synchronic data. It has discussed several issues that are of general interest in relativization, typology, syntax and grammaticalization. Among other things, it was observed that in Nkami both the head noun and its referent within the RC are obligatorily and explicitly stated, save when the referent within the RC is an inanimate in non-subject function. Thus, Nkami is among the very few languages that employ the pronoun retention strategy to obligatorily state relativized NPs functioning as subject within the RC.

The paper also departed from the analysis of some Kwa linguists by recognizing a marker, which is similar in distribution and function to what is so-called 'Clause (final) Determiner CD', as a Relative Marker. Hence, Nkami's RCC is viewed as one that employs a 'bracket strategy', where two enclosing relative makers $n I ́$ and amó are simultaneously placed at the ends of the RC. Moreover, unlike other Ghanaian Kwa languages such as Akan and Ewe, the head noun modified by a relative clause never takes a definite determiner, e.g. amó 'the/that' and $n a$ ' 'this'. The RC in Nkami always restricts the reference of the head noun, hence there is no element whether segmental, suprasegmental, or written that is employed to mark the difference between 'restrictive' and 'non-restrictive' RCs. Thus, Nkami's RCCs help to provide support for earlier observations made by some linguists (cf. Watters 2000, Saah 2010) that the distinction between restrictive and non-restrictive RCs is generally not marked in African languages.

\section{Abbreviations}

$\begin{array}{llll}\text { ANIM } & \text { animate } & \text { PDP } & \text { proximate distal prefix } \\ \text { CONJ } & \text { conjunction } & \text { PPD } & \text { proximal predicative demonstrative } \\ \text { CONTIN } & \text { continuative } & \text { PST } & \text { past } \\ \text { DEF } & \text { definite article } & \text { PRF } & \text { perfect } \\ \text { DEM } & \text { demonstrative } & \text { PL } & \text { plural } \\ \text { DDP } & \text { distal directional prefix } & \text { POSS } & \text { possessive } \\ \text { DPD } & \text { distal predicative demonstrative } & \text { PROG } & \text { progressive } \\ \text { FOC } & \text { focus } & \text { RED } & \text { reduplication } \\ \text { FUT } & \text { future } & \text { REL } & \text { relative marker } \\ \text { HAB } & \text { habitual } & \text { SG } & \text { singular } \\ \text { INANM } & \text { inanimate } & \text { SUBJ } & \text { subject } \\ \text { NEG } & \text { negation } & & \end{array}$




\section{References}

Aboh, Enoch O. 2010. The Morphosyntax of the Noun Phrase. In Aboh, Enoch O. \& James Essegbey (eds.), Topics in Kwa Syntax. London \& New York: Springer Dordrecht Heidelberg. $11-38$.

Akanlig-Pare, G. \& Rogers K. Asante. 2016. Vowel harmony in Nkami. Journal of West African Languages 43 (1): 21-44.

Asante, Rogers. K. 2016. Nkami language: Description and analysis. $\mathrm{PhD}$ dissertation, Tongji University, Shanghai.

Asante, Rogers. K. \& G. Akanlig-Pare. 2015. Animacy in Nkami. Ghana Journal of Linguistics 4 (2):64-91.

Baker, Carl L. 1978. Introduction to Generative-transformational Syntax. New Jersey: Prentice-Hall.

Besnier, Niko. 2000. Tuvaluan: A Polynesian Language of the Central Pacific. London: Routledge.

Boadi, Lawrence. 1976. A note on the historical antecedents of the obligatory pronoun -3- deletion rule in the Akan dialects. Acta Linguistica Hafniensia, 16: 1-10.

Bybee, Joan. 2003. Cognitive Process in Grammaticalization. In Tomasello, Michael (ed.) The New Psychology of Language: Cognitive and Functional Approaches to Language Structure, Volume II. New Jersey: Lawrence Erlbaum Associates Incorporated. 145-167.

Casali, Roderic F. 2002. [ATR] value asymmetries and underlying vowel inventory structure in Niger-Congo and Nilo-Saharan. Linguistic Typology, 7: 307-382.

Chomsky, Noam. 1981. Lectures on Government and Binding. Dordrecht: Foris.

Chumbow, Beban. 1977. Relatives as Determiners: A Case from Ngemba. In Kotey, P.F.A \& H. Der-Houssikian (eds.), Language and Linguistic Problems in Africa. Proceedings of the VII Conference on African Linguistics. South Carolina: Hornbeam Press. 283-302.

Comrie, Bernard. 1976. Aspect. Cambridge: Cambridge University Press.

Comrie, Bernard. 1981. Language Universals and Linguistic Typology. Chicago: University of Chicago Press.

Comrie, Bernard.1998. Rethinking the Typology of Relative Clauses. Language Design, 1: 59-86.

Comrie, Bernard \& Smith, Norval. 1977. Lingua Descriptive Studies: Questionnaire. Lingua, 42: $1-72$.

Dakubu, Mary E. 1988. The languages of Ghana. London: Kegan Paul International.

Diessel, Holger. 1999. Demonstratives: Form, Function and Grammaticalization. Amsterdam: John Benjamins.

Dixon, Robert M. W. 1997. The Rise and Fall of Languages. Cambridge: Cambridge University Press.

Dixon, Robert M. W. 2003. Demonstratives: A Cross-linguistic Typology. Studies in language, 27:61-112.

Dixon, Robert M. W. 2004. The Jawaraa Language of Southern Amazonia. Oxford: Oxford University Press.

Dixon, Robert M. W. 2010. Basic Linguistic Theory, Volume II. Oxford: Oxford University Press. Dorvlo, Kofi. 2008. A Grammar of Logba. The Netherlands: LOT.

Genetti, Carol. 2007. A grammar of Dolakha Ncwar. Berlin: Mouton de Gruyter.

Givón, Thomas. 2001. Syntax, Volumes I \& II. Amsterdam \& Philadelphia: John Benjamins. 
Hagège, Claude. 1970. La langue Mbum de Nganha (Cameroun). Paris: SELAF [Bibliothèque de la Société pour l'Étude des Langages Africaines 18-19].

Heine, Bernd; Claudi, Ulrike; \& Hünnemeyer, Friederike. 1991. Grammaticalization: A Conceptual Framework. Chicago: University of Chicago Press.

Heine, Bernd \& Kuteva, Tania. 2002. World Lexicon of Grammaticalization. Cambridge: Cambridge University Press.

Keenan, Edward L.1985. Relative clauses. In Shopen (ed.), Language Typology and Syntactic Description, Volume II. Cambridge: Cambridge University Press. 141-170.

Keenan, Edward L. \& Comrie, Bernard. 1977. NP Accessibility and Universal Grammar. Linguistic Inquiry, 8: 63-100.

Kibrik, Andrej. 1992. Relativization in Polysynthetic Languages. International Journal of American Linguistics, 58: 135-157.

Kuteva, Tania \& Comrie, Bernard. 2005. The Typology of Relative Clause Formation in African Languages. In Voeltz, F. K. Erhard (ed.), Studies in African Linguistics Typology. Amsterdam \& Philadelphia: John Benjamins. 209-228.

Lefebvre, Claire. 1993. Dominance versus Precedence in the Double Object Construction: New Facts from Fongbe. Canadian Journal of Linguistics, 38: 395-424.

Lehmann, Christian. 1984. Der Relativsatz: Typologie seiner Strukturen, Theorie seiner Funktionen, Kompendium seiner Grammatik. Tübingen: Gunter Narr Verlag.

McCawley, James D. 1998. The Syntactic Phenomena of English, 2nd ed. Chicago \& London: University of Chicago Press.

Osam, Kwaku E. 2003. An Introduction to the Verbal and Multi-Verbal System of Akan. In Beermann, Dorothee \& Hellan Lars (eds.), Proceedings of the Workshop on Multi-Verb Constructions Trondheim Summer School.

Osam, Kwaku E. Unpublished Manuscript. Relativization in Akan.

Payne, Thomas E. 1997. Describing Morphosyntax: A Guide to Field Linguists. Cambridge: Cambridge University Press.

Perlmutter, David M. \& Soames, Scott. 1979. Syntactic Argumentation and the Structure of English. Berkeley \& Los Angeles: University of California Press.

Saah, Kofi K. 1992. Null Object Constructions in Akan. In Collins, Chris \& Victor Manfredi (eds.), Proceedings of the Kwa Comparative Syntax Workshop (= MIT Working Papers in Linguistics), 17:219-244.

Saah, Kofi K. 2010. Relative Clauses in Akan. In Aboh, Enoch O. \& James Essegbey (eds.), Topics in Kwa Syntax. London \& New York: Springer Dordrecht Heidelberg. 91-107.

Sankoff, Gillian, \& Brown, Penelope. 1976. The Origins of Syntax in Discourse: A Case Study of Tok Pisin Relatives. Language, 52: 631-666.

Schachter, Paul. 1973. Focus and Relativization. Language, 49.1 19-46.

Schaub, Willi. 1985. Babungo. London: Croom Helm.

Stewart, John M. 1963. Some Restrictions on Objects in Twi. Journal of African Languages, 2:145-149.

Stockwell, Robert P. 1977. Foundations of Syntactic Theory. New Jersey: Prentice-Hall.

Sweet, Henry. 1891. A New English Grammar, Logical and Historical. Oxford: Clarendon Press.

Watters, David E. 2002. A grammar of Kham. Cambridge: Cambridge University Press. 
Watters, John R. 2000. Syntax. In Heine, Bernd \& Derek Nurse (eds.), African Languages: An Introduction. Cambridge: Cambridge University Press. 194-230.

Rogers Krobea Asante nanarogs@yahoo.com

Qiuwu Ma

tjnkmqw@126.com
Submitted: 18 May 2015

Accepted: 1 Aug 2015

Revisions received: 18 May 16 